\title{
FACILITATING CREATIVE PROBLEM SOLVING IN THE MARKETING CURRICULUM IN RESPONSE TO THE DEMANDS OF THE NETWORKED INFORMATION SOCIETY
}

\author{
Denise Wood, University of South Australia, Australia \\ Noel J. Lindsay, The University of Adelaide, Australia \\ Stuart Gluth, University of South Australia, Australia \\ Ron Corso, University of South Australia, Australia \\ Carolyn Bilsborow, University of South Australia, Australia
}

\begin{abstract}
This paper describes a systems approach to creative problem solving designed to better prepare marketing graduates for the uncertainties of the networked information society. This is in response to the growing need for future graduates to be able to make effective use of participatory Web 2.0 technologies for building customer relationships and harnessing their creative potential to collaboratively influence and improve product development, and to market products more effectively. The paper outlines alternative marketing paradigms, describes the attributes required of graduates to be able to maximize the potential of Web 2.0 technologies, and the role that creativity plays in developing graduates' ability to think critically, identify and solve problems, and communicate effectively. The failure of traditional approaches in teaching and learning to facilitate student creativity is discussed and a systems approach to creative problem solving designed to address these identified challenges is proposed. Illustrative examples of the use of the approach in graduate and undergraduate courses are presented and the potential for integration within the marketing curriculum is discussed.
\end{abstract}

\section{INTRODUCTION}

The long standing business and marketing paradigm based on the assumption that a customer-centric approach leads to value creation and increased firm profit performance (Rust and Zahorik 1993) has been challenged by some researchers who argue that, given times of uncertainty, a less customer-centric approach is more appropriate. However, this alternative paradigm fails to acknowledge the growing body of evidence in support of the effective use of participatory Web 2.0 technologies for building customer relationships and harnessing their creative potential to collaboratively influence and improve product development and reach a larger market. This paper outlines a third paradigm, focusing on the increasing importance of engaging with customers as both "produsers" (Bruns 2008) and marketers through social media, and the creativity skills required of future graduates to make more effective use of these technologies to solve increasingly complex problems, build customer relationships, and market products more effectively.

\section{ALTERNATIVE BUSINESS AND MARKETING MODELS}

This section provides a discussion of the evolution from what should be industry best-practice in moving from a product-centric to a customer-centric marketing model. While theoretically this has occurred, in practice, most firms still cling to their products at the expense of focusing on their customers. Exacerbating this problem is an emerging technology wild card that now dictates a new emergent customer participatory model to replace (or at least extend) the traditional customer-centric model. Firms that do not embrace the emergent technological changes, and the new and innovative ways of doing business that are associated with these changes, face serious consequences.

\section{The Move from Product-Centricity to Customer-Centricity}

At the completion of World War II, there was a significant customer pent-up demand for new products. During this period, the marketing function focused on "... promoting, pricing, and distributing products for the mass market" (Sheth, Sisodia, and Sharma 2000, p. 55) with profits aligned to the market-share firms obtained. Firms were internally focused with an emphasis on producing superior products vis-à-vis being customer or consumer centric. During the 1950s, as competition increased, significant changes occurred in marketing thinking and there was an impetus for firms to move from product to market orientations. It was during this period that the contemporary marketing concept evolved (Sheth et al. 2000). Accelerating the metamorphosis from product to market focus were the huge leaps in ICT in the latter half of the $20^{\text {th }}$ Century. These provided significant advancements in the collection, storage, analysis, and transmission of information. These advancements provided the basis to enhance relationships with customers via 
investment in customer relationship management systems and database software marketing packages so as to reach out and provide "personalized" attention to valuable customers.

A key mainstay underpinning the marketing concept is that firm success in the marketplace is achieved through putting the concerns of the customer foremost. Customer-centric firms develop a competitive advantage because they are able to respond to different customer groups with a somewhat personalized service tailored to the customer's needs (Galbraith 2005). Firms that develop this capability are more likely to attract and maintain satisfied loyal customers and both practitioners and researchers agree that this is a key contributor to firm success (Rust and Zahorik 1993). Although evidence of the importance of customer satisfaction continues to accrue, there are many in industry that fail to appreciate that firm success is linked to customer satisfaction. The reality is that most firms remain product-centric despite the rhetoric that they have a customer focus (Galbraith 2005).

\section{Post Customer-Centricity: An Emerging Participatory Model}

While many firms remain in "catch-up" mode in moving on from a predominantly product focus, technological advances have yet again underpinned changes to how new age customers want to be involved in the marketing function. Web 2.0 (a group of technologies that are associated with terms such as blogs, wikis, podcasts, and RSS feeds that facilitate a more socially connected World Wide Web where individuals are able to augment and modify the information space) provides the basis for building customer relationships by empowering customers to not only be managed through customer relationship management systems, but to actively contribute in their capacity as product users - "produsers" (Bruns 2008).

Obasanjo's (2004) classification of social software enables us to easily identify the core features and particular applications that incorporate the principles of social networking espoused by O'Reilly (2005). Obasanjo (2004) identified five classes of social software ... communication, sharing, discovery of old and new contacts, relationship management, and collaborative gaming. These applications are well suited to "produsage", which Bruns (2008) suggests is characterized by community-based production, fluid roles, unfinished artefacts, and common property. This kind of "produsage" is said to erode the production and marketing value chain by increasing the capacity of more diverse non-market producers to both produce and market goods by collapsing the cost of producing and exchanging information, thus elevating informal social marketing to a more central role in the information economy. Consumers are also using this new democratic marketplace to shape public perception of products and services through effective use of Web 2.0 social media. This phenomenon has resulted in a clash between traditional institutionalised approaches to production and marketing, and emerging social practice.

Another significant trend emerging in parallel with this shift toward more participatory modes of production, marketing, and distribution has been the emergence of a new generation of digitally literate "produsers": These young people are said to display particular characteristics including the ability to multi-task, a desire for immediacy, a preference for multi-modal learning, a need to be socially connected through networked activities, responding best to experiential activities, and an interest in "things that matter". It is also argued that these "net gen" learners are entering university already equipped with skills in the use of a wide range of Web 2.0 applications such as wikis, social networking, blogging, podcasts, and 3D gaming. However, evidence is also mounting of the challenges in adapting these technologies to the teaching and learning curriculum.

The increasing demand to equip graduates with both the ability to respond to an increasingly complex world and the ability to make effective use of new and emerging technologies, requires a new paradigm in marketing education; one that leverages off the digital literacy of our changing student and customer demographic. This includes those who develop their creative capacity through lateral thinking to develop problem solving skills and who make effective use of social media. Thus, it is timely to develop a new kind of customer relationship model whereby the "produsers" are the ones who contribute to the development of products and market them via wider Web 2.0 based distribution channels. In this regard, Table 1 provides a comparison of the product-, customer-, and produser-centric approaches.

\section{NEED FOR CREATIVITY IN AN INCREASINGLY COMPLEX NETWORKED INFORMATION SOCIETY}

It is evident from the preceding discussion that the shift to a networked information society has profound implications. The combination of technological developments and globalization, combined with volatile markets and increasing uncertainty in a complex networked society, necessitates fundamental changes in the ways in which firms identify 
problems and solutions, market their products, and respond to customer demands. Such shifts also necessitate changes in the skills required in the marketplace since working with complex problems requires the ability to think creatively, synthesize information, make connections, evaluate alternatives, and implement solutions (Jackson 2006).

The need for a more creative workforce, one that is able to respond to complex and uncertain times, is a recurring theme in the literature (Florida 2003). It is argued that the key to economic growth necessitates both the ability to attract such a creative workforce as well as the ability to translate this advantage into new ideas, business generation, and economic growth (Florida 2003). High quality ideas are assumed to underpin effective management and ineffective management suggests the adoption of poor quality ideas. Creativity underpins the development of novel and valuable ideas by individuals or small groups of individuals operating together. Creativity and innovation (something new that creates value in the eyes of the consumer) are therefore seen as crucial to the success of businesses in the networked information society of the $21^{\text {st }}$ Century. While innovation is not new; history shows that there always has been a propensity to change the way things are done so as to improve the quality of our lives (Fagerberg 2005).

It should be evident from this discussion, that the demands of our increasingly complex world and the challenge of responding to uncertainty require a different set of graduate attributes. This represents a radical departure from the routine problem solving tasks that have characterized the information age (Florida 2003). The marketing firms of the $21^{\text {st }}$ Century require graduates who are able to undertake creative work in environments that are increasingly dependent on digital technologies and who can make effective use of customer relationship management using social media, while also responding to the demands of the "product-innovation-diffusion-stasis cycles of economic production" (McWilliam 2007, p. 5). Yet, despite consensus about these changing workforce demands, there is compelling evidence that universities are failing to equip graduates with the creative skills required to be effective in the workplace

\section{NEED FOR CREATIVITY IN THE HIGHER EDUCATION CURRICULUM}

In what has come to be regarded as a seminal presentation to the American Psychological Association, Guildford (1950) drew attention to the lack of research addressing the creative aspects of personality, arguing that since a creative act is an instance of learning, a comprehensive learning theory must take into account both insight and creative activity (p. 446). Guildford further pointed to the demand from industry and government for graduates with leadership skills who demonstrate the ability to lead, plan, and inspire vision. It should be self-evident that nurturing creativity in higher education is even more critical to meeting the needs of an increasingly complex and uncertain future (Jackson 2006).

However, although many universities acknowledge the importance of creativity within the curriculum, most programs are structured around achieving certain graduate qualities that elevate traditional education methodologies and practice, based on knowledge acquisition and retention, rather than creativity. Emphasis in education has been mostly concerned with what De Bono (1973) calls vertical thinking, the process of proving and developing concept patterns, whereas lateral or creative thinking sets out to restructure such patterns and provoke new ones. Tosey (2006) suggests that creativity in the higher education curriculum is more often used "to converge and control" (p.35) than to engage productively "at the edge of order" (Fullan, cited in Tosey, p.34). Thus, McWilliam (2007) asserts that universities need a much higher preparedness to tolerate failure which contributes to the tension between creativity and control. While it is evident that fostering creativity is "best achieved through a process-based or activity-based curriculum that engages students in challenging, novel and unpredictable ways of working and learning" (Jackson 2006, p. 213), the strategies for achieving this goal have remained elusive. Our research aims to demystify some of these limiting attitudes through the development of an idea generation framework within a creative problem solving approach.

\section{FRAMEWORK FOR CREATIVE PROBLEM-SOLVING IN THE HIGHER EDUCATION CURRICULUM}

In the preceding sections the case has been made for embedding strategies for facilitating creativity in the higher education curriculum to better prepare graduates for the challenges of an uncertain future and develop their abilities to solve complex problems in the networked information era. In this section we outline a proposed framework, adapted from the well established Creative Problem-Solving (CPS) model, for use in the marketing curriculum.

\section{A Systems Approach to Creativity}

Creativity involves producing novel and useful ideas or products. In defining creativity in this way, we acknowledge that creativity can be learned and assessed, and that there are several factors that either facilitate or impede the 
achievement of creativity performance. This view is consistent with Csikszentmihalyi's (1999) systems approach to creativity, which considers the interaction among three subsystems: the domain, the person, and the field.

While the development of problem-solving ability is recognized as a primary goal of the education process, the role of creativity as being fundamental to the process of problem solving has largely been overlooked (Ruscio and Amabile 1999). This finding is perhaps somewhat perplexing since, by definition, "creativity is exhibited when an individual solves a problem in a way that is novel and appropriate (or valuable)" (Ruscio and Amabile 1999, p. 2). According to Amabile (1996), there are three main components of creative performance. These are: domain-relevant skills, creativity-relevant processes, and task motivation. This approach recognizes that domain-relevant skills (for example, facts, principles, technical skills, and opinions) are required for a learner to have access to the full range of response possibilities from which a new response is to be synthesized, and the information against which the new response is to be judged (Csikszentmihalyi 1999). Creativity is more likely to be facilitated when the task is intrinsically motivating (the experience of learning is its own reward) (Csikszentmihalyi 1999).

\section{The Creative Problem Solving Approach}

Creative Problem-Solving (CPS) has its roots in the work of Osborn (1953) who developed CPS as an aid to the understanding the different phases of creative problem-solving. Amabile's (1996) componential framework of creativity incorporates a similar CPS approach, which is described as a sequence to response generation process. This process incorporates five steps: (1) problem or task identification; (2) preparation; (3) response generation; (4) response validation and communication; and (5) outcomes. We have adapted aspects of Amabile's (1996) componential framework of creativity and Titus's (2000) CPS model within a systems approach involving a six stage creative problem solving process. Our model recognizes the impact that the domain, field, and individual factors (Csikszentmihalyi 1999) have on the creative problem solving process (see Figure 1). In the next section, we elaborate on the techniques we have found to be successful in facilitating the ability for students to generate ideas during the creative problem solving process.

\section{Idea Generation}

Throughout this paper, we have argued that the increasingly participatory approach to production, marketing, and distribution, together with the increasing demand to equip graduates with the ability to respond to an increasingly complex world reinforces the need for renewed focus on the role of creativity in higher education pedagogy (McWilliam 2007). There is little doubt that certain aspects of creativity can be fostered through formal and informal learning (McWilliam 2007) and the systems approach to creative problem solving outlined in this paper provides a scaffold for learners. It has also been argued that ideation (idea generation) is a required aspect of each stage of the creative problem solving process and that divergent ideation is critical to the generation of novel pathways to problem solving.

Ideation depends on the restructuring of existing ideas, knowledge, technology, and systems into new models and configurations. This represents models of information shifts or inventiveness that generate new meanings. Such a perception shift allows us to transfer key ideas to another application. To achieve this goal, students need to know how to observe the unexpected by modelling processes of random association and careful observation of accidental juxtaposition. The following list of ideation techniques that support this approach have been informed by the primary creative abilities identified in the Guilford Test of Divergent Thinking and the Torrance Tests of Creative Thinking. We argue that these can be fostered within the curriculum and, to this list, we add additional techniques drawn from the literature (see for example De Bono 1973), which together comprise the following 12 techniques incorporated into our creativity framework:

1. Fluency of ideas involving the generation of a large number of possibilities

2. Flexibility of ideas that encourages restructuring of information to create new configurations

3. Challenging Assumptions to break patterns of behavior and facilitating the unexpected

4. Deconstructing the problem and solving the parts then recombining those to give unexpected combinations. It is much easier to solve the "little" bits than to come up with an overall solution for all problem aspects at once.

5. Random Association to make connections between things even when they are not apparent

6. Intuition, focusing and disciplining it by modelling, trust, relaxation and allowing time and space

7. Risk taking and making mistakes to explore possibilities without penalty if they don't work 
8. Group and collaborative work reacting to each other's proposals and conversations

9. Sensory Activity less-likely ways of exploring the problem and subsequent possible solutions

10. Analogies and Metaphors making associations that create more than the sum of two ideas

11. Lists cross referencing items either randomly or systematically demands new possibilities, and

12. Removing inhibitors increasing participants' confidence to explore and try things when the outcomes are not always clear and they're conditioned to having to come up with the single 'right' answer.

Table 2 classifies these techniques according to the four categories of ideation techniques (visioning, modifying, exploring/discovering, and experimenting) adapted from The Global Creativity Corporation's Innovation Styles System and cross-referenced against the different stages of the creative problem solving process.

This approach to idea generation is designed to engage students by building confidence in an environment where outcomes are not known or expected. Creative outcomes are by definition not predictable; they are about possibilities. This model is based on valuing all parts of the process, not just the final outcomes, and all attempts, including failure - especially where learning takes place. In particular, the model should be structured so that learning does take place from failing, and students overcome a fear of failing. It is also important to start with simple means with reduced complexity ... allowing students to make many little creative jumps, without much risk, so that they succeed quickly and easily, and gain confidence so that they gain an understanding of how basic principles work, simply and fast, building up to more complex and "meaningful" work as confidence and understanding is achieved, both consciously and unconsciously. In this next section, we describe how the systems approach to creative problem solving has been applied across a range of disciplinary fields including marketing, event management, entrepreneur training and media arts.

\section{CPS PROCESS IN PRACTICE}

The benefits of introducing creativity within the marketing curriculum are well documented in the literature (Titus 2000). Titus (2000) has shown how the creative problem solving approach applies to the marketing process (see p. 227). We have adapted this model to show the ways in which social media can scaffold the CPS process in the marketing curriculum, and the corresponding ways in which social media may be used in the marketing process (Figure 2).

During the first stage of this creative solving process, divergent thinking needs to be encouraged to enable individuals to embark on a process of problem discovery, beginning with the generation of many possible areas of focus before subsequently refining the number and focus to the specific problem or task to be investigated. During the second stage, problem delineation, individuals refine their ideas about the problem they have chosen to investigate/explore, and in the case of marketing, this involves focusing on a given target market. This stage logically leads to the next involving information gathering, which in turn builds the individual's domain knowledge. Social media plays a part here in enabling students to refine their ideas based on peer feedback, and companies can test out market response through two-way dialogue with potential customers facilitated via a blog, wiki or discussion forum. The third stage, information gathering, involves the exploration of novel approaches to solving the problem (divergent thinking) and gathering information (moving from divergent to convergent thinking). For the student, this stage will typically involve obtaining primary, secondary, and/or tertiary sources that provide the foundation for a literature review or market analysis, which can be recorded via their "ideas" blog. Domain knowledge is critical at this stage. By the fourth stage, both creativity relevant skills as well as task motivation are important (Amabile 2006). Generally, the more options that an individual can generate, the more likely that he/she will generate more novel approaches to a solution. As with the first stage, social media plays an important role in supporting collaboration as individuals brainstorm ideas to produce unexpected combinations of ideas. The fifth stage involves evaluation and validation of the responses generated during the previous stages of the creative problem solving process. By this stage, there is a shift from divergent thinking to convergent thinking as individuals critically examine the ideas generated during the previous stages of the CPS process (Titus 2000). Not surprisingly, domain-relevant skills are required at this stage as individuals judge the quality of their ideas against existing knowledge. Social media also plays a role in enabling companies to test out their proposed solutions in the market place prior to final implementation. The sixth stage involves decision-making and completion of a task or implementation of a marketing plan. The process will either terminate or cycle back through all of the stages of the CPS process if the individual has been unable to complete the previous stage successfully. The use of social media as a mechanism for gauging community acceptance of ideas as they are generated and possible solutions has an important role to play in mitigating the potential of reaching such roadblocks at the final stage of the CPS process. 


\section{CONCLUDING COMMENTS}

This paper outlines a systems approach to creative problem solving based on approaches that have been found to be effective and that are widely reported in the literature. The approach we describe is scaffolded through the effective use of social media in ways that appeal to "net gen" learners, while also facilitating the development of their creative problem solving skills through a structured approach incorporating reflection, collaboration, peer review, and "produsage". We have shown how the CPS approach aligns with contemporary marketing approaches that harness the power of social media to engage with customers using innovative strategies for building and maintaining customer relationships. The introduction of a systems approach to creative problem solving is not without its challenges as described in the preceding sections. As with the CPS process itself, the implementation of the systems approach to creative problem solving in the marketing curriculum requires a cyclic approach involving ongoing revision and refinement based on student feedback. The use of social media throughout a course provides a valuable medium for formative feedback for both students and teachers. This enables students to act on feedback progressively, and teachers to adopt a reflexive approach, adjusting their teaching on the basis of the continual feedback provided through student blogs and the course wiki. Similarly, the use of social media enables marketers to monitor consumer responses to their initiatives thereby enabling them to similarly adopt a reflexive approach to building customer relationships.

Table 1: Comparison of the Product-Centric, Customer-Centric, and Produser Centric Approaches (adapted from Shah, Rust, Parasuraman, Staelin, \& Day, 2006)

\begin{tabular}{|c|c|c|c|}
\hline & Product-Centric Approac & Customer-Centric Approach & Produser-Centric Approach \\
\hline $\begin{array}{l}\text { Basic } \\
\text { philosophy }\end{array}$ & $\begin{array}{l}\text { Sell products; we'll sell to } \\
\text { whoever will buy }\end{array}$ & $\begin{array}{l}\text { Serve customers; all decisions st } \\
\text { with the customer and } \\
\text { opportunities for advantage }\end{array}$ & $\begin{array}{l}\text { Customers contribute to the design, } \\
\text { development, decision-making and market } \\
\text { process }\end{array}$ \\
\hline $\begin{array}{l}\text { Business } \\
\text { orientation }\end{array}$ & Transaction-oriented & Relationship-oriented & Relationship and network oriented \\
\hline $\begin{array}{l}\text { Product } \\
\text { positioning }\end{array}$ & $\begin{array}{l}\text { Highlight product features an } \\
\text { advantages }\end{array}$ & $\begin{array}{l}\text { Highlight product's benefits in } \\
\text { terms of meeting individual } \\
\text { customer needs }\end{array}$ & $\begin{array}{l}\text { Highlight customers' ability to contribute } \\
\text { the design of solutions that meet their need } \\
\text { and to market the products through the use } \\
\text { social media }\end{array}$ \\
\hline $\begin{array}{l}\text { Organization } \\
\text { structure }\end{array}$ & $\begin{array}{l}\text { Product profit centres, produc } \\
\text { managers, product sales team }\end{array}$ & $\begin{array}{l}\text { Customer segment centres, } \\
\text { customer relationship managers, } \\
\text { customer segment sales team }\end{array}$ & $\begin{array}{l}\text { Requires expertise in facilitating engageme } \\
\text { with customers through social networking }\end{array}$ \\
\hline $\begin{array}{l}\text { Organizati } \\
\text { focus }\end{array}$ & $\begin{array}{l}\text { Internally focused, new produ } \\
\text { development, new account } \\
\text { development, market share } \\
\text { growth; customer relations ar } \\
\text { issues for the marketing } \\
\text { department }\end{array}$ & $\begin{array}{l}\text { Externally focused, customer } \\
\text { relationship development, } \\
\text { profitability through customer } \\
\text { loyalty; employees are customer } \\
\text { advocates }\end{array}$ & $\begin{array}{l}\text { Externally focused, customer relationship } \\
\text { development, profitability through custome } \\
\text { loyalty and customers' contribution to the } \\
\text { design, development and marketing proces } \\
\text { employees are customer advocates and } \\
\text { customers are advocates for company and } \\
\text { each other }\end{array}$ \\
\hline $\begin{array}{l}\text { Performance } \\
\text { metrics }\end{array}$ & $\begin{array}{l}\text { Number of new products, } \\
\text { profitability per product, mar } \\
\text { share by product/subbrands }\end{array}$ & $\begin{array}{l}\text { Share of wallet of customers, } \\
\text { customer satisfaction, customer } \\
\text { lifetime value, customer equity }\end{array}$ & $\begin{array}{l}\text { Share of wallet of customers, customer } \\
\text { satisfaction, customer lifetime value, } \\
\text { customer equity, growth in innovation }\end{array}$ \\
\hline $\begin{array}{l}\text { Management } \\
\text { criteria }\end{array}$ & Portfolio of products & Portfolio of customers & $\begin{array}{l}\text { Portfolio of customers as 'produsers' (both } \\
\text { producers and customers/users) }\end{array}$ \\
\hline $\begin{array}{l}\text { Selling } \\
\text { approach }\end{array}$ & $\begin{array}{l}\text { How many customers can we } \\
\text { sell this product to? }\end{array}$ & $\begin{array}{l}\text { How many products can we sell } \\
\text { this customer? }\end{array}$ & $\begin{array}{l}\text { How many products can we sell this } \\
\text { customer and how many products can } \\
\text { customers sell for the company? }\end{array}$ \\
\hline $\begin{array}{l}\text { Customer } \\
\text { knowledge }\end{array}$ & $\begin{array}{l}\text { Customer data are a control } \\
\text { mechanism }\end{array}$ & $\begin{array}{l}\text { Customer knowledge is valuable } \\
\text { asset }\end{array}$ & $\begin{array}{l}\text { Customer knowledge is valuable asset and } \\
\text { essential for innovation }\end{array}$ \\
\hline
\end{tabular}


Table 2: A Framework for Creative Problem-Solving using Idea Generation Techniques adapted from Titu (2000), Gluth and Corso (2009), and Innovation Styles and Market Comparison (The Global Creativity Corporation 2007)

\begin{tabular}{|c|c|c|c|c|}
\hline \multirow{2}{*}{ CPS Stages } & \multicolumn{4}{|c|}{ Idea Generation (Ideation) Techniques } \\
\hline & Visioning & Modifying & Exploring/Discovering & Experimenting \\
\hline $\begin{array}{l}\text { Problem } \\
\text { Identification }\end{array}$ & $\begin{array}{l}\text { Fluency of ideas } \\
\text { involving generation } \\
\text { of large number of } \\
\text { possibilities } \\
\text { Brainstorming } \\
\text { Use of guided imager } \\
\text { Collaborating and } \\
\text { discussing to } \\
\text { generate ideas } \\
\text { Using social media to } \\
\text { enable community to } \\
\text { submit their ideas } \\
\text { Using blog to reflect }\end{array}$ & $\begin{array}{l}\text { Refining what other } \\
\text { have done using: } \\
\text { SCAMPER } \\
\text { technique: } \\
\text { (s)ubstituting } \\
\text { (co)mbining } \\
\text { (m)odifying } \\
\text { (p)ut to use } \\
\text { (e)liminating } \\
\text { (r)arranging } \\
\text { Modifying ideas } \\
\text { based on peer } \\
\text { feedback and } \\
\text { discussion } \\
\text { Using social media } \\
\text { create mash-ups of } \\
\text { ideas }\end{array}$ & $\begin{array}{l}\text { Cross referencing items } \\
\text { either randomly or } \\
\text { systematically demands } \\
\text { new possibilities } \\
\text { Sensory Activity to } \\
\text { facilitating exploring the } \\
\text { problem and subsequent } \\
\text { possible solutions } \\
\text { Using analogies and } \\
\text { metaphors making } \\
\text { associations that create } \\
\text { more than the sum of two } \\
\text { ideas }\end{array}$ & $\begin{array}{l}\text { Removing inhibitors } \\
\text { increasing } \\
\text { participants' } \\
\text { confidence to explor } \\
\text { and try things when } \\
\text { the outcomes are not } \\
\text { always clear and } \\
\text { they're conditioned t } \\
\text { having to come up } \\
\text { with the single 'right } \\
\text { answer }\end{array}$ \\
\hline Problem Delineatiol & $\begin{array}{l}\text { Intuition to understan } \\
\text { the bigger picture } \\
\text { Refining the problem } \\
\text { Deconstructing the } \\
\text { problem } \\
\text { Mindmapping } \\
\text { Storyboarding } \\
\text { Using blog to refine } \\
\text { thinking and reflect }\end{array}$ & $\begin{array}{l}\text { SCAMPER - } \\
\text { combining the } \\
\text { deconstructed } \\
\text { components in new } \\
\text { ways } \\
\text { Challenging } \\
\text { assumptions to breal } \\
\text { patterns of behavior } \\
\text { and facilitating the } \\
\text { unexpected } \\
\text { Random Association } \\
\text { to make connections } \\
\text { between things even } \\
\text { when they are not } \\
\text { apparent }\end{array}$ & $\begin{array}{l}\text { Using intuition as } \\
\text { springboard for } \\
\text { exploration }\end{array}$ & $\begin{array}{l}\text { Assessing componen } \\
\text { to identify "leverage } \\
\text { points" and } \\
\text { opportunities for new } \\
\text { approaches }\end{array}$ \\
\hline $\begin{array}{l}\text { Information } \\
\text { Gathering }\end{array}$ & $\begin{array}{l}\text { Seeking information } \\
\text { on the big picture and } \\
\text { component parts } \\
\text { guided by intuition an } \\
\text { refinement of the } \\
\text { problem }\end{array}$ & $\begin{array}{l}\text { Considering multipl } \\
\text { sources and then } \\
\text { looking for } \\
\text { springboards to new } \\
\text { sources - forming } \\
\text { new associations }\end{array}$ & $\begin{array}{l}\text { Challenging assumptions } \\
\text { to generate new ways of } \\
\text { addressing the research } \\
\text { process } \\
\text { Undertaking research } \\
\text { using a variety of sources }\end{array}$ & $\begin{array}{l}\text { Combining findings } \\
\text { from sources to help } \\
\text { refine the solution or } \\
\text { to generate new idea } \\
\text { to springboard furthe } \\
\text { areas and sources for } \\
\text { research }\end{array}$ \\
\hline
\end{tabular}




\begin{tabular}{|c|c|c|c|c|}
\hline & $\begin{array}{l}\text { Using blog to capture } \\
\text { thoughts and } \\
\text { document research } \\
\text { findings } \\
\text { Sharing findings via } \\
\text { wiki and bookmarkin } \\
\text { sites }\end{array}$ & 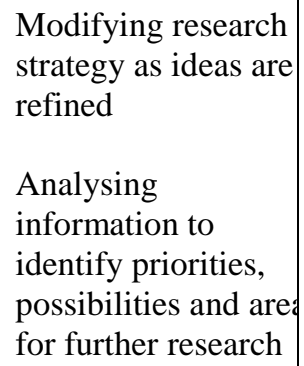 & $\begin{array}{l}\text { Web, social media, } \\
\text { library, databases, } \\
\text { broadcast media, primary } \\
\text { sources) and then refining } \\
\text { research process } \\
\text { Seeking different sources } \\
\text { of information }\end{array}$ & \\
\hline $\begin{array}{l}\text { Experimentation an } \\
\text { Validation }\end{array}$ & $\begin{array}{l}\text { Using visionary } \\
\text { techniques employed } \\
\text { to generate and } \\
\text { identify problem to } \\
\text { come up with novel } \\
\text { solutions } \\
\text { Using blog to } \\
\text { document experiment } \\
\text { and reflect on the } \\
\text { outcomes } \\
\text { Collaborating via blo } \\
\text { and discussion forum }\end{array}$ & $\begin{array}{l}\text { Moving from } \\
\text { divergent } \\
\text { manipulations of } \\
\text { information to } \\
\text { convergent } \\
\text { refinement to focus } \\
\text { on practical solution }\end{array}$ & $\begin{array}{l}\text { Risk taking and making } \\
\text { mistakes to explore } \\
\text { possibilities without } \\
\text { penalty if they don't work } \\
\text { leading to refinement and } \\
\text { weighing up the solutions } \\
\text { to arrive at practical } \\
\text { solutions }\end{array}$ & $\begin{array}{l}\text { Risk taking and } \\
\text { making mistakes } \\
\text { without penalty if the } \\
\text { don't work, leading t } \\
\text { refinement and } \\
\text { weighing up the } \\
\text { solutions to arrive at } \\
\text { practical solutions } \\
\text { Building on the } \\
\text { solutions that have } \\
\text { been shown to be } \\
\text { more likely to lead to } \\
\text { success }\end{array}$ \\
\hline Implementation & $\begin{array}{l}\text { "Produsage" using } \\
\text { social media } \\
\text { Discussion, peer } \\
\text { review, use of web } \\
\text { metrics and formal } \\
\text { evaluation } \\
\text { Personal blog for } \\
\text { reflection on process } \\
\text { Public blog for gainin } \\
\text { feedback }\end{array}$ & $\begin{array}{l}\text { Modifying approach } \\
\text { if initial } \\
\text { implementation } \\
\text { needs further } \\
\text { refinement }\end{array}$ & $\begin{array}{l}\text { Exploring the unique } \\
\text { contribution the innovatio } \\
\text { has made through market } \\
\text { research and evaluation }\end{array}$ & $\begin{array}{l}\text { Evaluating and } \\
\text { examining success } \\
\text { and identifying areas } \\
\text { for future } \\
\text { improvement. }\end{array}$ \\
\hline
\end{tabular}


Figure 1: A Systems Approach to Creative Problem Solving (CPS) adapted from Amabile (1996), Csikszentmihalyi (1999), and Titus (2000)

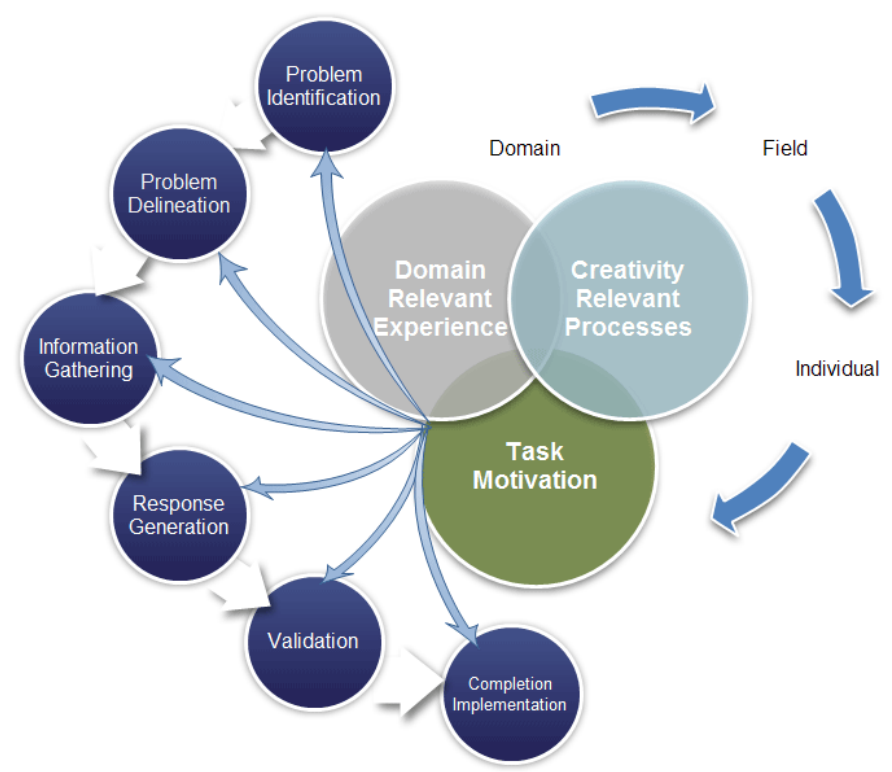

Figure 2: An adapted CPS Approach to Teaching and Learning using Social Media illustrating the Relationship between CPS and the Marketing Process (adapted from Titus 2000)

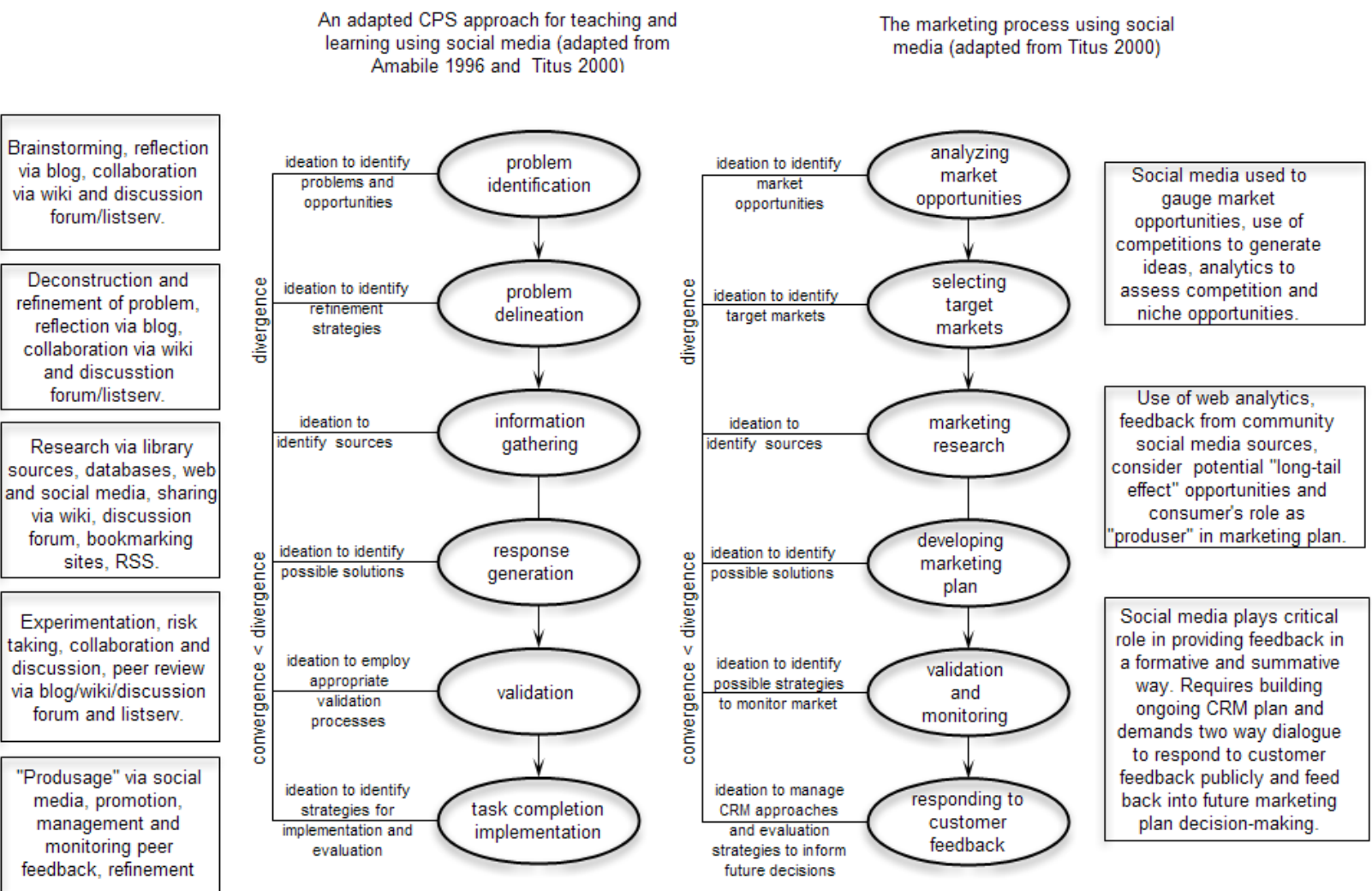




\section{REFERENCES}

Amabile, T. M. (1996). Creativity in context: Update to the social psychology of creativity. Boulder, CO: Westview.

Bruns, A. (2008). Blogs, Wikipedia, Second Life, and beyond: From production to produsage. New York: Peter Lang.

Csikszentmihalyi, M. (1999). Implications of a systems perspective for the study of creativity. In R. Sternberg (Ed.), Handbook of creativity. UK: Cambridge University Press.

De Bono, E. (1973). Lateral thinking: Creativity step by step. New York: Harper Paperbacks.

Fagerberg, J. (2005). Innovation: A guide to the literature review, in The Oxford handbook of innovation. Fagerberg, J., Mowery, D., \& Nelson, R. Oxford University Press, Oxford; New York.

Florida, R. (2003). The rise of the creative class: and How it's transforming work, leisure, community and everyday life. Victoria: Pluto Press.

Galbraith, J. (2005). Designing the customer-centric organization. Jossey-Bass: A Wiley Imprint, San Francisco.

Guilford, J. P. (1950). Creativity. American Psychologist, 5(9), 444-454.

Jackson, N. (2006). Imagining a different world. In N. Jackson, M. Oliver, M. Shaw \& J. Wisdom (Eds.), Developing creativity in higher education: An imaginative curriculum (pp. 1-9). London and New York: Routledge.

McWilliam, E. (2007). Is creativity teachable? Conceptualising the creativity/pedagogy relationship in higher education. Paper presented at the Proceedings 30th HERDSA annual conference : Enhancing higher education, theory and scholarship, Adelaide.

Obasanjo, D. (2004). Dare Obasanjo aka Carnage4Life - social software is the platform of the future. Retrieved 16 December, 2008, from http://www.25hoursaday.com/weblog/PermaLink.aspx?guid=06ff2206-27a3-4d55-81d8$\underline{\text { bbee37073d6d }}$

O'Reilly, T. (2005). What is Web 2.0: Design patterns and business models for the next generation of software. O'Reilly Media Inc. Retrieved December 29, 2010 from http://www.oreillynet.com/pub/a/oreilly/tim/news/2005/09/30/what-is-web-20.html

Osborn, O. (1953). Applied imagination: Principles and procedures of creative problem solving. New York: Charles Scribner's Sons.

Ruscio, A. M., \& Amabile, T. M. (1999). Effects of instructional style on problem-solving creativity. Creativity Research Journal, 12(4), 251.

Rust R., \& Zahorik A. J. (1993). Customer satisfaction, customer retention, and market share. Journal of Retail, 69, 193- 215 [Summer].

Shah, D., Rust, R.T., Parasuraman, A., Staelin, R., \& Day, G.S. (2006). The path to customer centricity. Journal of Service Research, 9: 113-124, http://jsr.sagepub.com/content/9/2/113

Sheth, J.N., Sisodia, R.S., \& Sharma, A. (2000). Journal of the Academy of Marketing Science, 28 (1), 55-66.

Titus, P. A. (2000). Marketing and the creative problem-solving process. Journal of Marketing Education, 22(3), 225235.

Tosey, P. (2006). Interfering with the interference: An emergent perspective on creativity in higher education. In N. Jackson, M. Oliver, M. Shaw \& J. Wisdom (Eds.), Developing creativity in higher education: An imaginative curriculum. (19-28). London: Routledge 